\title{
Influence of the administration of propolis and bee pollen preparation on the concentration of mercury in the muscles, kidneys and liver of white storks
}

\author{
JOSE L. VALVERDE PIEDRA*, AGATA ZIENKIEWICZ*,**, HUSSEIN B. KHUDHUR*,***, \\ SYLWIA E. SZYMAŃCZYK ${ }^{* * * *}$, EWA RUMIŃSKA*****

\begin{abstract}
*Sub-Department of Toxicology and Environmental Protection, Department of Preclinical Veterinary Sciences, Faculty of Veterinary Medicine, University of Life Sciences, Akademicka str. 12, 20-950 Lublin, Poland

**'Medivet' Veterinary clinics, Słowackiego str. 2i, 11-010 Barczewo, Poland

***Public Health Department, College of Veterinary Medicine, University of AL Muthanna. Al Samawa, Irak

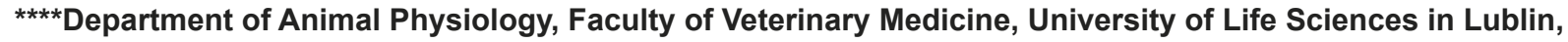
Akademicka str. 12, 20-950 Lublin, Poland

*****Wild Birds Rehabilitation Centre, Albatross Foundation, Bukwałd 45a, 11-001 Dywity, Poland
\end{abstract}

Valverde Piedra J. L., Zienkiewicz A., Khudhur H. B., Szymańczyk S. E., Rumińska E.

Influence of the administration of propolis and bee pollen preparation on the concentration of mercury in the muscles, kidneys and liver of white storks

\section{Summary}

A total of ninety white storks (Ciconia ciconia) of both sexes aged over one year of life and at a body weight between 2.8-4.15 kg were subjects for observations. They were collected from the Warmia and Masuria region, and were rehabilitees of The Wild Birds Rehabilitation Center (Bukwald, Poland). The storks formed a group of birds that had wing damage like broken bones and were unable to fly. According to the severity of the case storks underwent three different kinds of treatment. Light cases of motion disability were submitted to wing or leg stabilization with adhesive bandages (treatment I), while middle and severe cases were additionally submitted to the administration of one (treatment II) or two capsules (treatment III) of propolis and pollen bee preparation (Apipol Farma's Propolis Plus ${ }^{\circledR}$ ) for two weeks, respectively. After the convalescence period a total of twenty three white storks did not recover and were euthanized and dissected. Post mortem samples of pectoral and femoral muscles as well as liver and kidney samples were taken. Mercury concentration was analyzed and the results revealed that the level in the kidneys and liver of white storks not receiving propolis preparation were significantly higher than that of those from treatment II and III. Contrary to this, the mercury concentration recorded in the pectoral and femoral muscles of the birds of treatment II and treatment III were significantly higher than that of the treatment without propolis preparation. The results showed that propolis and pollen bee preparation can reduce the level of mercury in kidneys and liver, but has no influence on the reduction of mercury in pectoral and femoral muscles.

Keywords: mercury, pollen bee, propolis, white stork

Mercury is one of the most ubiquitous toxic metals and environmental contaminants. This is because mercury is an element that once it is released even in small amounts into habitats occupied by birds and other wildlife it does not break down, but instead accumulates and becomes a permanent part of the global environment $(2,5,19)$. One of the most insidious aspects of mercury pollution is that all forms of mercury, whether in its liquid elemental form or in various compounds, can be biologically transformed into the most toxic form, methylmercury $(\mathrm{Me}-\mathrm{Hg})(1,19)$. This form of mercury has been shown to be extremely hazardous to humans and wildlife animals. Birds in general seem to be especially sensitive to $\mathrm{Me}-\mathrm{Hg}(1,19)$. It is biomagnified in the avian food chain and reaches high levels, especially in fish eating birds like the white stork (2). The chemical structure of mercury affects its biological behavior and toxicokinetics. Methyl and dimethyl mercury (organic mercury) usually originate in biological sources, chiefly fresh or salt water fish (14). They are easily absorbed through the gut and accumulate in many tissues, but do not cross the blood-brain barrier as efficiently as elemental mercury; however, on entering the brain they are progressively demethylated to 
elemental mercury (2). In contrast mercury salts tend to be insoluble, relatively stable and poorly absorbed (9). Elemental mercury has a high affinity to sulfhydryl groups and binds to glutathione or metallothioneine, and interferes with intercellular signaling and the activity of enzymes inhibiting the development of the central nervous system, stimulating the onset of neurological illnesses $(1,8,9)$.

White storks are semi-pescivorus birds and their diet contains small fish, amphibians, reptiles, birds, mammals, and non-vertebrate animals like earthworms (13). As white storks live in wetlands, they can be exposed to mercury. They have the opportunity to prey in different areas of Europe, Asia and Africa according to their migration, and at the same time to assimilate the mercury from food $(5,11)$. In wildlife birds, most cases of mercury poisoning result in an emaciation syndrome and a variety of sub lethal effects that may act together to cause death $(2,17)$.

Recently there has been growing interest in the utilization of natural compounds primarily as an alternative medicine to avoid the unfavorable side effects which result from xenobiotics. As a natural compound of a bee's derivate product, propolis is a common name for a complex of various plant exudates mixture that contains a broad spectrum of biologically active compounds collected by honey bees $(10,12)$. It is mainly used in construction, adaptation and protection of bee hives $(5,7)$. Bee pollen is composed of amino acids, proteins, lipids, carbohydrates, enzymes, phenolic compounds as well as vitamins $(4,10)$. Among other properties it has been reported that bee pollen has the ability to guard against intoxication from heavy metals through its anti-oxidative effect (10).

Taking into consideration the lack of information on the use of bee preparations in wild living birds the aim of this treatment was to evaluate the usefulness of propolis and bee pollen to enforce a healing and convalescence period in wounded white storks (Ciconia ciconia). Additionally, the postmortem samples of selected tissues provided the opportunity for the inspection on the level of mercury accumulation in these birds.

\section{Material and methods}

The study was performed in the years 2015-2016, excluding winter time, and comprised ninety white storks of both sexes at the age of over one-year of life and body weight between $2.8-4.15 \mathrm{~kg}$. The storks came from the Warmia and Masuria region, and were patients of The Wild Bird Rehabilitation Center (Bukwald, Poland). All birds were transported to the center because of various wing and leg injuries (broken bones, joint luxations) which made them unable to fly. The storks were examined during the acceptance to the center and according to the severity of the mobility dysfunction were classified to three different treatments.

During the convalescence period the storks received one-day old dead turkey chicks from the Gerczak Poultry Hatchery ${ }^{\circledR}$ (Laseczno, Poland) at the amount of 10 chicks per stork, once a day as a fodder. The storks stood in a external run, with full access to fresh and clean water.

Light cases of motion disability were submitted to wind or leg stabilization with adhesive bandages (treatment I). In order to improve the health and bone fracture healing process, the storks of middle and severe cases were additionally submitted to the administration of one (treatment II) or two capsules (treatment III) of a propolis and pollen bee preparation (Apipol Farma's Propolis Plus ${ }^{\circledR}$ ) for two weeks, respectively. The preparation used in the treatment contained in each capsule $275 \mathrm{mg}$ of flower pollen and $25 \mathrm{mg}$ of concentrated bee's propolis.

After the convalescence period the white storks, which were still unable to fly and could not be released were euthanized by decapitation. In total 7 birds from the treatment one, nine from treatment II and seven from treatment III were euthanized. The samples of liver, kidneys, pectoral and femoral muscles were isolated and washed with chilled saline solution and frozen for further analysis. All tissue samples were weighted, put into plastic jars and submitted to a freeze drying process. The tissue samples were powdered using an agate ball mill for 15 minutes, then transferred into ziploc bags. To determine total mercury, the cold vapor atomic absorption spectrometry (CV-AAS) technique was used. The amount of 33 to $55 \mathrm{mg}$ of each sample was placed in between two layers of reagents in a porcelain boat and inserted into the heating stove $\left(800^{\circ} \mathrm{C}\right)$ of the Mercure Analyzer Mercury/MA-2000 System (NIC-Japan). The mercury vaporized from the sample and values were detected and registered and calculated as $\mu \mathrm{g} / \mathrm{kg}$ of wet tissue weight.

Statistical analysis. The mean and standard error were calculated for each variable. The data were analyzed by the analysis of variance (ANOVA) to identify the significant differences among groups at $(\mathrm{P}<0.05)$, with post-hoc Tukey multiple comparison test using SPSS software statistical program (SPSS for windows ver.16.00, USA).

\section{Results and discussion}

The highest concentration of mercury was found in the kidney (1.8-5.8 $\mu \mathrm{g} / \mathrm{kg}$ wet tissue), a middle range concentration was found in the liver $(0.5-1.9 \mu \mathrm{g} / \mathrm{kg}$ wet tissue) and the lowest concentration in the pectoral and femoral muscles (0.33-0.92 and 0.68-1.43 $\mu \mathrm{g} / \mathrm{kg}$ wet tissue, respectively) of the white storks.

Mercury concentration in liver and kidney. The liver and kidneys of the storks in treatment I showed a significantly higher concentration of mercury $(1.88 \pm 0.24$ and $5.81 \pm 0.67 \mu \mathrm{g} / \mathrm{kg}$ wet tissue, respectively) as compared to the storks of treatment II $(0.5 \pm 0.1$, kidney $2.51 \pm 0.61 \mu \mathrm{g} / \mathrm{kg}$ wet tissue, respectively; $\mathrm{P}<0.05)$ and treatment III $(0.73 \pm 0.13$, $1.77 \pm 0.34 \mu \mathrm{g} / \mathrm{kg}$ wet tissue, respectively; $\mathrm{P}<0.05)$, but no significant differences appeared between the mean values of treatment II and III (Fig. 1).

Mercury concentration in pectoral and femoral muscles. Mercury concentrations in the pectoral muscle of white storks from treatment I and treatment II were significantly lower than that for treatment III $(\mathrm{P}<0.05)$. No significant differences were 


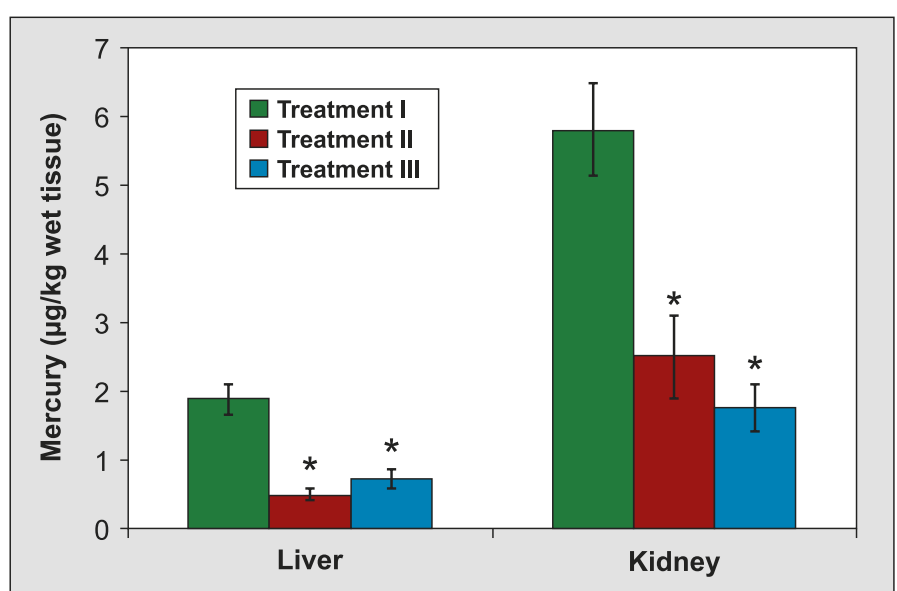

Fig. 1. Mercury levels in the liver and kidneys of white storks after treatment with and without propolis and pollen bee preparation during the convalescence period

Explanation: ${ }^{*}$ - significant differences between treatments at $\mathrm{P}<0.05$

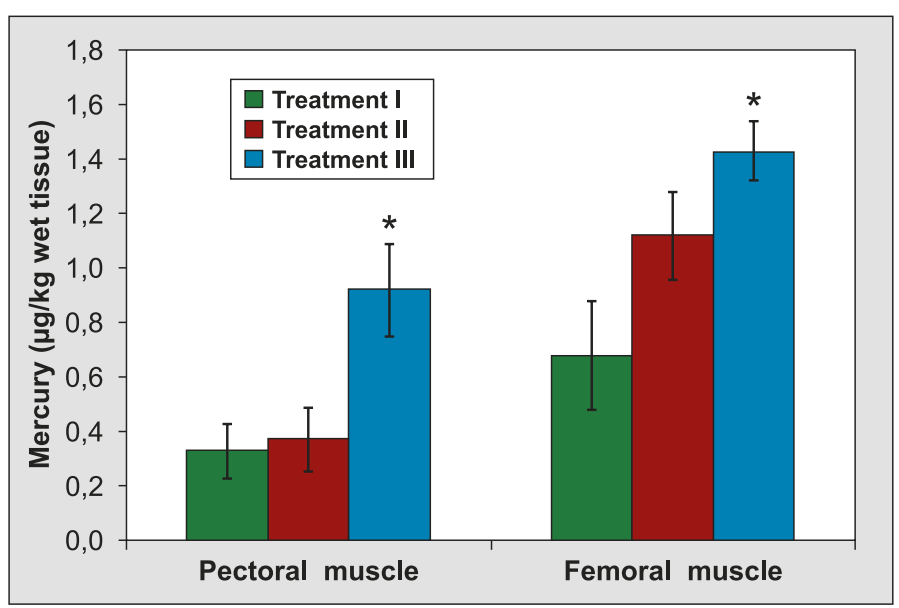

Fig. 2. Mercury levels in the muscles of the white storks after treatment with and without propolis and pollen bee preparation during the convalescence period Explanation: as in Fig. 1.

found among treatment I and treatment II. The average mercury concentration for pectoral muscles of the treatment I, treatment II and treatment III was $0.33 \pm 0.1$, $0.37 \pm 0.12,0.92 \pm 0.17 \mu \mathrm{g} / \mathrm{kg}$ wet tissue, respectively (Fig. 2).

Mercury concentrations in the femoral muscle of white storks for the treatment I was significantly lower than for treatment II and treatment III $(\mathrm{P}<0.05)$. No significant differences were found between treatment II and III. The average mercury concentration for the femoral muscle of the storks of treatment I, treatment II and treatment III was $0.68 \pm 0.2,1.12 \pm 0.35$, $1.43 \pm 0.15 \mu \mathrm{g} / \mathrm{kg}$ wet tissue (Fig. 2).

In the last few years the white stork populations in Poland and Western Europe have seen decline. Researchers linked this to the pollution of their environment by heavy metals and other xenobiotics $(3,11$, 13). Storks, as wild birds that are related to agriculture and rural environment can be presented as an indicator for mercury or other heavy metals pollution (11).
It is difficult to diagnose the causes of heavy metal pollution in the wild birds, especially when their history is unknown. Mercury is deposited in the natural ecosystem through natural processes and the human activities which have the highest impact on nature, as they can nearly triple the amount of mercury in the atmosphere (17). In living organisms it may cause an increase in the production of the reactive oxygen species, because it leads to the depletion from the cell of major thiol-containing antioxidants which result in a condition known as oxidative stress $(8,20)$.

In a conventional treatment, to eliminate mercury from the body calcium-EDTA or penicillaminase is used, although they show a poor therapeutic effect, thus alternative natural medications could be a better solution in order to improve the protection of the environment $(1,5)$. The propolis mechanism of action against mercury toxicity is not fully known, but it is believed that it can increase the elimination of heavy metals from the tissues through its antioxidant activity and metal chelating ability $(5,7,10,21)$. Due to the presence of flavonoids and phenolic compounds, which are powerful free radical scavengers, propolis protects the cell membrane from lipid peroxidation $(12,21)$. Propolis is widely used in human medicine because of its antimicrobial, antiviral, antifungal, immunostimulating and antioxidant activity, but little is known about its influence on wild birds. For its multiple health protecting features, propolis was used in these treatments. We discovered that propolis and bee pollen can reduce the level of mercury in kidneys and liver; however, as a result of redistribution the level of mercury increases in the femoral and pectoral muscles of the birds treated with the preparation. This can be explained by the releasing of mercury ions from the bones, cartilages or adipose tissue and its transport in the circulatory system to metabolically more active muscles, as they are well supplied with blood vessels. Ions can be transported to the skin and feathers on the way to elimination. It is noteworthy that the overall concentration of mercury found in the examined organs and tissues of the birds treated with propolis and bee pollen preparation was $48.3 \pm 7.6(49.2-39.4 \%)$ and $44.3 \pm 5.9 \%(53.9-42.7 \%)$ lower in comparison to untreated ones.

The results showed that the accumulation of mercury in the bodies of white storks takes place, but the level is not very high. This is interesting since all birds were collected from the least contaminated part of Poland (Warmia and Masuria), since the industry production in this area represents only $2.3 \%$ of the Polish industry (18). It is difficult to define if mercury deposition in a soft tissue of a white storks is the result of local area pollution or the result of a past migration outside the Europe as happens to other birds (15). A study at University of East Anglia in Portugal revealed that white storks have changed their migrating behavior very radically (University of East Anglia. 
"Why have white storks stopped migrating?" Science Daily, 27 February 2013: <www.sciencedaily.com/ releases/2013/02/130227085845.htm). This could happen due to climate changes, since they stay in the country instead of flying to Africa. They can easily prey on rubbish dumps, which provides heavy metal polluted food $(13,16)$.

In conclusion propolis and bee pollen effectively lowered the level of mercury in the kidneys and liver in the white stork and could be used as an alternative treatment for the elimination of this and perhaps other xenobiotics affecting the health of wild birds during the convalescence period. Although the amount of samples from birds in this study is limited, the results clearly show the lowering effect on mercury concentration in soft tissues of the storks treated with propolis preparation. However, further studies should be performed on a larger group of storks to confirm the propolis effects not only on mercury elimination but also on the elimination of other heavy metals. This will be a relevant insight into the health status of the white stork and could serve for the development of advanced programs regarding the species' protection.

\section{References}

1. Bernhoft R. A.: Mercury Toxicity and Treatment: A Review of the Literature. J. Environ. Public Health 2012, 1-10. doi:10.1155/2012/460508.

2. Bossche W. van den: Eastern European white stork populations: migration studies and elaboration of conservation measures. Bundesamt für Naturschutz (bfn)/German Federal Agency for Nature Conservation 2002, p. 57-118.

3. Burger J., Gochfeld M.: Risk mercury levels and birds: relating adverse laboratory effects to field bio monitoring. Environ. Res. 1997, 75, 160-172.

4. Campos M., Firgerio C., Lopes J., Bogdanov S.: What is the future of BeePollen? J. Analyt. Atom. Spectrom. 2010, 2, 131-144.

5. Castaldo $S$., Capasso F.: Propolis an old remedy used in modern medicine. Fitotropa 2002, 73. suppl. 1, s1-s6.

6. Clarkson T. W.: Mercury: major issues in environmental health. Environ. Health Perspect. 1992, 100, 31-38.

7. Eraslan G., Kanbur M., Silici S., Liman B., Altinordulu S., Sarica Z.: Evaluation of protective effect of Bee-Pollen against propoxur toxicity in rat. Ecotox. Environ. Safety. 2009, 72, 931-937.
8. Ercal N., Gurer-Orhan H., Aykin-Burns N.: Toxic metals and oxidative stress. Part I: mechanisms involved in metal induced oxidative damage. Curr. Topics Med. Chem. 2001, 1, 529-539.

9. Fernandez Azevedo B., Barros Furieri L., Maciel Peçanha F., Wiggers G. A., Frizera Vassallo P., Ronacher Simões M., Fiorim J., Rossi de Batista P. Fioresi M., Rossoni L., Stefanon I., Alonso M. J., Salaices M., Vassallo $D$. $V$ : Toxic effects of mercury on the cardiovascular and central nervous systems. J. Biomed. and Biotechnol. 2012, Article ID 949048, 11 pages. doi:10.1155/2012/949048.

10. Frozzan C., Garcia C., Gambato G.: Chemical characterization antioxidant and cytotoxic activities of Brazilian red propolis. Food Chem. Toxicol. 2013, 52, 137-142.

11. Kaminski P., Kurhalyuk N., Szady-Grad M.: Heavy metals induced oxidative stress and changes in physiological process of free radicals in the blood of white storks (Ciconia ciconia) checks in polluted areas. Polish J. Environ. Stud. 2007, 16, 555-562.

12. Kolankaya D., Selmanoglu G., Sorkun K., Salih B.: Protective effects of Turkish propolis on alcohol induced serum lipid changes and liver injury in male rats. Food Chemistry 2002, 78, 213-217.

13. Kosicki J. Z., Profus P., Dolata P. T., Tobotka M.: Food composition and energy demand of the White Stork Ciconia ciconia breeding population. Literature survey and preliminary results from Poland, [in:] Tryjanowski P., Sparks T. H., Jerzak L. (eds): The White Stork in Poland: studies in biology, ecology and conservation. Bogucki Wydawnictwo Naukowe, Poznań 2006, p. 169-183.

14. Langeland A. L., Hardin R. D., Neitzel R. L.: Mercury levels in human hair and farmed fish near artisanal and small-scale gold mining communities in the Madre de Dios River basin, Peru. Int. J. Environ. Res. Public Health 2017, $14,302-320$.

15. Ofukany A. F. A., Hobson K. A., Wassenaar L. I.: Connecting breeding and wintering habitats of migratory piscivorous birds: Implications for tracking contaminants $(\mathrm{Hg})$ using multiple stable isotopes. Environ. Sci. Technol. 2012 , 46, 3263-3272.

16. Pirrone N., Ferrara R., Hedgecock M., Kallos G., Mamane Y., Munthe J. Dynamic processes of mercury over the Mediterranean Atmospheric Mercury cycle system (MAMCS) Project. Atoms. Environ. 2003, 37 (suppl. 1), 21-39.

17. Rice K. M., Walker E. M. Jr, Wu M., Gillette C., Blough E. R.: Environmenta mercury and its toxic effects. J. Prev. Med. Public Health 2014, 47, 74-83.

18. Rocznik Statystyczny Województw (wybrane tablice). Główny Urząd Statystyczny, Warszawa 2012-01-24, p. 58-59.

19. Scheuhammer A. M., Meyer M. W., Sandheinrich M. B., Murray M. W.: Effect of environmental methylmercury on the health of wild birds, mammals, and fish. Ambio 2007, 36, 12-18.

20. Song K. B., Lee Y. E., Jeong S. H., Kim H. Y., Kwon H. K.: Mercury distribution and concentration in rats fed powdered dental amalgam. Arch. Oral Biol. 2002, 47, 307-313.

21. Viuda Martos M., Ruiz Navajas Y., Fernández López J., Pérez Álvarez J. A.: Functional Properties of Honey propolis and Royal Jelly. J. Food Sci. 2008, 73, 117-124.

Corresponding author: dr hab. Jose Luis Valverde Piedra prof. nadzw., ul. Topolowa 19, 21-003 Dys, Poland; e-mail: jose.valverde@up.lublin.pl 